\title{
INFLUENCE OF CERTAIN BIO AND CHEMICAL TREATMENTS ON SUGAR PEA PRODUCTIVITY AND PROTECTION OF SOME INSECT PESTS
}

\author{
ALI, T.B ${ }^{1}$. AND A.A.A. ABD-ALLAH ${ }^{2}$ \\ 1. Veg. Res. Dept., Hort. Res. Inst., ARC, Giza \\ 2. Vegetable Pests Res. Dept., Plant Protection Res. Inst., ARC, Dokki, Giza
}

(Manuscript received 15 October 2009)

\begin{abstract}
This study was carried out during the winter seasons of 2007/2008 and 2008/2009 at the Experimental Farm of El Kassasein Research Station, Ismailia Governorate, to investigate the effect of spraying with vitamins $\left(B_{1}\right.$ and $\left.C\right)$ at rates 50 and 100 $\mathrm{mg} / \mathrm{L}$, yeast at rates 2 and $4 \mathrm{~g} / \mathrm{L}$ and different combination treatments of them as well as control on vegetative growth, yield and its components, chemical constituents and protection from pea leaf miner (Liriomyza pisi), leguime aphids (Aphis craccivora Koch) and two spotted spider mite (Tetranychus urtica Koch) attacking pests of sugar pea cv. Gaint grown in sandy soil under drip irrigation system. plants were sprayed three times at 20, 34 and 48 days after sowing

The results indicated that vegetative growth, yield and its components and chemical constituents were promoted with all spraying materials as compared to control (sprayed with water), and spraying plants with vitamins ( $B_{1}$ and $C$ ) at two concentrations recorded the uppermost values of growth, pod quality, total yield and chemical constituents than yeast .

Generally, spraying plants with mixture vitamins ( $B_{1}$ and $\left.C\right)$ and yeast at all concentrations significantly increased vegetative growth, yield and its components and chemical constituents than sprayed by vitamins ( $\mathrm{B}_{1}$ or $\mathrm{C}$ ) or yeast alone as well as control.

The previous results are supporting through the entomological study which indicted that:

1- The important role of vitamins ( $B_{1}$ and $C$ ) in plant physiological healthy which capable to resist the three pests.

2- Plants treated with yeast were more expose to infesting with pests because the yeast was more suitable to insect feeding.

3- Plants treated with $4 \mathrm{~g}$ yeast $+100 \mathrm{mg} / \mathrm{L}$ vitamin $B_{1}+100$ $\mathrm{mg} / \mathrm{L}$ vitamin $C$ were sufficient nutrient for plants and the same time to feeding the pests.

For this, the results show the great current of pest control concern about the environment indicates a need to limit application of chemicals for lank pests control.
\end{abstract}

\section{INTRODUCTION}

Sugar pea or snow peas (Pisum sativum var. macrocarpon) is one of the important newly introduced vegetable crops in Egypt. It has small edible pods that should be picked for their tenderness when very young, just as the seeds start to form, the pods could be shelled for their seeds because they will turn starchy. The 
young pods of sugar peas are flat, crispy, string-less, brittle, succulent and have wonderful flavour and sweatiness.

Recently, great attention has been focused on the possibility of using natural and safety substrates, i.e., vitamins and yeast in order to improve plant growth, yield (quantity and quality) and plants protection of pests.

Vitamin $B_{1}$ was found to favour sugar pea growth, total pods yield and exhibited a high total nitrogen and phosphorus (Kamel, 2005 and Omaima, 2009), increased total soluble solids (El-Ghamriny et al., 1999). Vitamin $B_{1}$ participates in plant growth and development indirectly by enhancing endogenous levels and various growth factors such as cytokinins and gibberllin (Kodandara and Rao, 1985).

Vitamin C functions as antioxidant, an enzyme factor and as growth regulating factor. It participates in a variety of processes, including photosynthesis, photoprotection, cell wall growth and cell expansion, resistance to environmental stresses and synthesis of ethylene, gibberellins, anthocynins and hydroxyproline (Nicholas and Wheeler, 2000 and Midan and El-Dinary, 2008). Spraying plants with vitamin $\mathrm{C}$ increased plant growth. It's exhibited a high total nitrogen and phosphorus in leave tissues, diminished number of pods/plant, augmented average pod weight and increased yield/plant (Omaima, 2009).

In addition, yeast is a natural source of many growth substances (thiamine, riboflavin, niacin, pyridoxine $\mathrm{HCl}$, pantothenate, bioten, cholin, folic acid and vitamin $\left.\mathrm{B}_{12}\right)$ and the most of nutritional elements ( $\mathrm{Na}, \mathrm{Ca}, \mathrm{Fe}, \mathrm{Mg}, \mathrm{K}, \mathrm{P}, \mathrm{S}, \mathrm{Zn}$ and $\mathrm{Si}$ ) as well as organic compounds,.i. protein, carbohydrates, nuclic acids and lipids (Nagodawithana, 1991). Spraying plants with yeast increased plant growth, chlorophyll in leaf tissues, NPK uptake and increased pod setting as well as total yield, average fruit weight and TSS (Abdel-Aziz, 1997 and El-Ghamriny et al., 1999).

Numerous investigators in different parts of the world have studied the main pest species and population density inhabiting by using natural substances in sugar pea (Bijjur and Verma, 1996). A variety of methods is recommended for the protection of some vegetable crops grown in open fields against pests include the use of liquid fertilizers to increase resistance of plants to insects and insecticide infusions based materials, biological preparations and synthetic chemicals (Zashchita 1991). In Egypt attention has been focused in the recent years on the possibility of using natural resistant varieties against leaf miner insect and mite pests on pea (Megali et al., 1992).

Present work aimed to study the possibility of using vitamins ( $B_{1}$ and $\left.C\right)$ and yeast to improve growth, flowering, pods quality, total yield and protection from some attacking pests of sugar pea. 


\section{MATERIALS AND METHODS}

Two field experiments were carried out during two successive winter seasons 2007/2008 and 2008/2009 at the Experimental Farm of El-Kassasin Horticultural Research Station, Ismailia Governorate, the experimental soil of the site area was sandy in texture with $8.1 \mathrm{pH}, 0.48 \%$ organic matter, $95 \mathrm{mg} / \mathrm{L} \mathrm{N}, 26 \mathrm{mg} / \mathrm{L} \mathrm{P}$ and 116 $\mathrm{mg} / \mathrm{L} \mathrm{K}$. The objective of these experiments was to determine the effect of vitamins $\left(B_{1}\right.$ and $\left.C\right)$ and yeast on growth, pods quality, total yield and protection of sugar pea (Pisum sativum var. macrocarpon) cv. Gaint to some insect pests. Seeds were sown in hills ( 2 seeds/hill) on two sides of drip irrigation row as $20 \mathrm{~cm}$ apart on $18^{\text {th }}$ and $23^{\text {th }}$ October in 2007 and 2008 seasons, respectively.

This experiment included 15 treatments as follows:

1- Control

2- $2 \mathrm{~g}$ yeast/L

3- $4 \mathrm{~g}$ yeast/L

4- $50 \mathrm{mg} / \mathrm{L}$ vitamin $B_{1}$

5- $100 \mathrm{mg} / \mathrm{L}$ vitamin $B_{1}$

6- $50 \mathrm{mg} / \mathrm{L}$ vitamin $C$

7- $100 \mathrm{mg} / \mathrm{L}$ vitamin $\mathrm{C}$

8- $2 \mathrm{~g}$ yeast $/ \mathrm{L}+50 \mathrm{mg} / \mathrm{L}$ vitamin $B_{1}+50 \mathrm{mg} / \mathrm{L}$ vitamin $C$

9- $2 \mathrm{~g}$ yeast $/ \mathrm{L}+50 \mathrm{mg} / \mathrm{L}$ vitamin $B_{1}+100 \mathrm{mg} / \mathrm{L}$ vitamin $C$

10- $2 \mathrm{~g}$ yeast $/ \mathrm{L}+100 \mathrm{mg} / \mathrm{L}$ vitamin $B_{1}+50 \mathrm{mg} / \mathrm{L}$ vitamin $C$

$11-2 \mathrm{~g}$ yeast $/ \mathrm{L}+100 \mathrm{mg} / \mathrm{L}$ vitamin $B_{1}+100 \mathrm{mg} / \mathrm{L}$ vitamin $C$

$12-4 \mathrm{~g}$ yeast $/ \mathrm{L}+50 \mathrm{mg} / \mathrm{L}$ vitamin $B_{1}+50 \mathrm{mg} / \mathrm{L}$ vitamin $C$

13- $4 \mathrm{~g}$ yeast $/ \mathrm{L}+50 \mathrm{mg} / \mathrm{L}$ vitamin $B_{1}+100 \mathrm{mg} / \mathrm{L}$ vitamin $C$

14- $4 \mathrm{~g}$ yeast $/ \mathrm{L}+100 \mathrm{mg} / \mathrm{L}$ vitamin $B_{1}+50 \mathrm{mg} / \mathrm{L}$ vitamin $C$

$15-4 \mathrm{~g}$ yeast $/ \mathrm{L}+100 \mathrm{mg} / \mathrm{L}$ vitamin $B_{1}+100 \mathrm{mg} / \mathrm{L}$ vitamin $C$

Yeast was mixed with sugar at ratio 1:1 and dissolved in water, then left for 2 hours before spraying.

The studied treatments were arranged in a randomized complete block design with three replications, except control treatment which have six replications for using three from them to spraying with pesticide (bensultap $50 \% \mathrm{Wp}$ ). The experimental unit area was $24 \mathrm{~m}^{2}$ which contained 8 rows with $5 \mathrm{~m}$ length for each and $60 \mathrm{~cm}$ width of them, four inner rows were possessed for yield determination, whereas the four outer rows were for determination of plant growth characters. One row was left between each two experimental plots to avoid the overlapping. Plants were sprayed three times at age 20, 33 and 48 days after sowing, the normal agricultural practices 
of sugar pea production under drip irrigation system of this area followed according to the recommendations of Ministry of Agriculture.

The common agricultural practices were followed regularly without any pesticide treatments throughout the growing seasons except three replications in control treatment were sprayed with bensultap $50 \% \mathrm{Wp}$ as a recommended pesticide for main pest attack sugar pea (pea leaf miner) according to the recommendations of Ministry of Agriculture after two weeks from the end of sprayed by vitamins ( $B_{1}$ and $\left.C\right)$ and yeast on other replications. $A$ knapsack sprayer equipped with one nozzle was used with rate $200 \mathrm{~L}$ spraying solution/fed.

Bensultap $50 \% \mathrm{Wp}$ is the natural insecticide and provided by Taked Chemical Industries, Ltd., chemical name S,S-2- dimethylaminotrimethylene di- (benzene thiosulfonate), trade name bensultap, Vietenon, 22 Doricida, Ruban. It was applied at the rate of $600 \mathrm{~g} / \mathrm{fed}$ water

\section{Data recorded}

\section{A. Plant Growth}

A random sample of six plants from each plot taken at flowering stage and the following data recorded plant height $(\mathrm{cm})$, number of leaves and branches/plant, Dry weight of whole plant $(g)$ :

A random sample of other six plants from each plot was taken and dried at $70^{\circ} \mathrm{C}$ till constant weight and the dry weight of whole plant was determined.

\section{B. Yield and Its Components}

Mature green pods were continuously harvested when reached suitable maturity stages. The following data were recorded:

1. Number of pods/plant $=\frac{\text { Total number of pods/plot }}{\text { Number of plants/plot }}$

2. Average pod length $(\mathrm{cm})$.

3. Average pod weight ( $\mathrm{g})$.

4. Early yield ( $\mathrm{Mg} / \mathrm{fed})[\mathrm{Mg}$ (mega grams) = million gram] (the sum of first and second pickings)

5. Green pods yield

Total green pods yield ( $\mathrm{Mg} / \mathrm{fed}$ ) was calculated on the base of total yield along harvesting stages by summing (the sum of all harvests).

C: NPK Contents and Uptake, Total protein, Total Carbohydrates and Total Soluble Solids

1. NPK Contents and Uptake 
Dried plants were finely ground separately and digested with sulphoric acid and percholoric acid (3:1) and nitrogen, phosphorus and potassium were determined according to the method described by Bremner and Mulvaney (1982), Olsen and Sommers (1982) and Jackson (1970), respectively and NPK uptake were calculated as NPK contents on dry weight basis (mg/plant).

2. Total protein (\%)

It was determined as nitrogen content and converted to its equivalent protein content by multiplying $\mathrm{N}$ content $\mathrm{X} 6.25$.

\section{Total Carbohydrates (\%)}

It was determined colorimetrically using the method described by Dubois et al. (1956).

4. Total soluble solids

A random sample of six green pods from the third picking were blended, filtrated throughout muslin cloth and then throughout filter paper No. 1, the total soluble solids (TSS) were finally determined in filtrated by Carlzies refractometer.

\section{D: Population Density of Pests}

Weekly samples of 10 leaflets of sugar pea were chosen and collecting from three levels (upper, middle and down) from 10 plants at random across a diagonal transect of each replicate starting lower in the first week of Nov. and the end of the second week of Nov. until the end week of Jan. during first and second seasons, respectively. The numbers of aphid (Aphis craccivora) on 10 leaflets were counted visual directly in the field. The pests found on same 10 leaflets were put in plastic sac and transferred to laboratory for examination by the aid of a stereo-microscope and recorded a live larvae of leaf miner (Liriomyza pisi.) inside the tunnels between the upper and lower surface of each leaflet and mite(Tetranychus urtica). The efficacy of the tested treatments was calculated according to Henderson and Tilton (1955).

\section{Statistical Analysis}

Data were tested by analysis of variance according to Snedecor and Cochran (1980) and the means separations were compared by using Least Significant Difference (LSD) at $5 \%$ level.

\section{RESULTS AND DISCUSSION}

\section{Plant Growth}

Results given in Table 1 show the effect of spraying plants with 50 and 100 $\mathrm{mg} / \mathrm{L}$ vitamin $B_{1}, 50$ and $100 \mathrm{mg} / \mathrm{L}$ vitamin $C, 2$ and $4 \mathrm{~g}$ yeast/L and different combination treatments among them as well as water spray (control) on growth aspects (plant height, number of branches and leaves /plant and dry weight/plant). 
It is obvious that vegetative growth was promoted with all spraying materials as compared to control.

Spraying plants with vitamins $B_{1}$ or $C$ at two concentrations under study recorded the uppermost values of plant height, number of branches and leaves/plant and dry weight/plant than yeast or control. Dry matter is the function of the environmental source and metabolic activities for sugar pea production, since it is the final outcome of plant growth and consequently affected yield and its attributes.

This may be due to vitamins participates in a variety of processes, including photosynthesis, photoprotection, cell wall growth and cell expansion, resistance to environmental stresses and synthesis of ethylene, gibberellins, anthocynins and hydroxyproline (Kodandara and Rao, 1985, and Midan and El-Dinary,2008).

Thiamine as well as ascorbic acid are necessary for the completion of reactions that lead to the formation of both chlorophyll and carotenoids in plant leaves. The changes in chlorophyll and chlorosis symptom may be used as a physiological and morphological signs of senescence in vegetables (Yamauchi and Alley 1991).

Meanwhile spraying plants with yeast at two concentrations had a significant increase on vegetative growth than control (sprayed with water), this may be due to yeast is a natural source of many growth substances (thiamine, riboflavin, niacin, pyridoxine, pantothenate, bioten, cholin, folic acid and vitamin $\mathrm{B}_{12}$ ) and the most of nutritional elements ( $\mathrm{Na}, \mathrm{Ca}, \mathrm{Fe}, \mathrm{Mg}, \mathrm{K}, \mathrm{P}, \mathrm{S}, \mathrm{Zn}$ and $\mathrm{Si}$ ) as well as organic compounds (protein, carbohydrates, nuclic acids and lipids), which reflected on plant growth (Nagodawithana, 1991).

The best treatment for increasing growth was spraying plants with mixture vitamins ( $B_{1}$ and $\left.C\right)$ and yeast at all concentrations under study as compared to sprayed by vitamins ( $B_{1}$ or $C$ ) or yeast alone as well as control. This may be due to spray with mixed vitamins $\left(B_{1}\right.$ and $\left.C\right)$ and yeast collection the beneficial of vitamins $\left(B_{1}\right.$ and $\left.C\right)$ and yeast together, which reflect on growth plant.

The obtained results are in accordance with those reported by El-Ghamriny et al., (1999), Midan and El-Dinary (2008) and Omaima (2009).

\section{Yield and Its Components}

Concerning the effect of spraying plants with different treatments on number of pods/plant, pod length, pod weight, early yield and total yield of sugar pea, it is obvious form Table 2 that all spraying treatments had a significantly increments in yield and its components as compared to control 
Table 1. Effect of vitamins ( $B_{1}$ and $C$ ) and yeast on vegetative growth of sugar pea throughout seasons 2007/2008 and 2008/2009.

\begin{tabular}{|c|c|c|c|c|c|c|c|c|}
\hline \multirow{2}{*}{$\begin{array}{l}\text { Characters } \\
\text { Treatments }\end{array}$} & \multicolumn{2}{|c|}{$\begin{array}{c}\text { Plant height } \\
\text { (cm) }\end{array}$} & \multicolumn{2}{|c|}{$\begin{array}{c}\text { No of } \\
\text { leaves/plant }\end{array}$} & \multicolumn{2}{|c|}{$\begin{array}{c}\text { No of } \\
\text { branches/plant }\end{array}$} & \multicolumn{2}{|c|}{$\begin{array}{c}\text { Dry matter/plant } \\
\text { (g) }\end{array}$} \\
\hline & First season & $\begin{array}{l}\text { Second } \\
\text { season }\end{array}$ & $\begin{array}{c}\text { First } \\
\text { season }\end{array}$ & $\begin{array}{l}\text { Second } \\
\text { season }\end{array}$ & $\begin{array}{c}\text { First } \\
\text { season }\end{array}$ & $\begin{array}{l}\text { Second } \\
\text { season }\end{array}$ & $\begin{array}{c}\text { First } \\
\text { season }\end{array}$ & $\begin{array}{l}\text { Second } \\
\text { season }\end{array}$ \\
\hline 1 & 47.67 & 46.67 & 48.42 & 46.66 & 4.18 & 4.18 & 7.57 & 7.61 \\
\hline 2 & 50.33 & 51.67 & 53.97 & 51.39 & 4.34 & 4.84 & 7.89 & 7.71 \\
\hline 3 & 53.00 & 52.67 & 52.66 & 52.41 & 4.90 & 3.69 & 7.80 & 7.45 \\
\hline 4 & 51.00 & 54.67 & 57.50 & 54.03 & 4.83 & 4.30 & 7.99 & 8.04 \\
\hline 5 & 57.67 & 54.33 & 57.43 & 55.31 & 5.00 & 4.76 & 8.03 & 8.01 \\
\hline 6 & 54.67 & 58.66 & 58.87 & 56.42 & 5.09 & 4.76 & 7.99 & 8.51 \\
\hline 7 & 56.00 & 60.33 & 59.43 & 57.93 & 5.22 & 5.04 & 8.81 & 8.46 \\
\hline 8 & 55.00 & 61.00 & 61.03 & 60.87 & 5.32 & 5.26 & 8.82 & 9.12 \\
\hline 9 & 56.00 & 57.67 & 62.52 & 59.41 & 5.21 & 5.16 & 9.32 & 9.35 \\
\hline 10 & 59.67 & 60.33 & 60.74 & 60.31 & 5.30 & 5.20 & 8.98 & 8.92 \\
\hline 11 & 60.33 & 58.33 & 58.38 & 59.06 & 5.16 & 5.30 & 9.64 & 8.78 \\
\hline 12 & 57.67 & 60.67 & 61.67 & 60.75 & 5.22 & 5.11 & 9.54 & 9.25 \\
\hline 13 & 58.67 & 60.67 & 60.53 & 59.19 & 5.00 & 5.21 & 9.53 & 9.53 \\
\hline 14 & 60.00 & 58.67 & 57.14 & 58.43 & 5.29 & 5.18 & 9.25 & 9.40 \\
\hline 15 & 60.67 & 59.33 & 59.64 & 57.29 & 5.41 & 5.27 & 9.61 & 9.49 \\
\hline $\mathrm{LSD}_{0.05}$ & 3.41 & 2.64 & 3.24 & 4.37 & 0.39 & 0.26 & 0.89 & 0.52 \\
\hline
\end{tabular}

1- Control

2- $2 \mathrm{~g}$ yeast/L

3- $4 \mathrm{~g}$ yeast/L

4- $50 \mathrm{mg} / \mathrm{L}$ vitamin $\mathrm{B}_{1}$

5- $100 \mathrm{mg} / \mathrm{L}$ vitamin $B_{1}$

6- $50 \mathrm{mg} / \mathrm{L}$

vitamin C

7- $100 \mathrm{mg} / \mathrm{L}$ vitamin C

8- $2 \mathrm{~g}$ yeast/L+

$50 \mathrm{mg} / \mathrm{L}$ vitamin $B_{1}+50 \mathrm{mg} / \mathrm{L}$ vitamin C

9- $2 \mathrm{~g}$ yeast $/ \mathrm{L}+50 \mathrm{mg} / \mathrm{L}$ vitamin $B_{1}+100 \mathrm{mg} / \mathrm{L}$ vitamin $C$

10- $2 \mathrm{~g}$ yeast $/ \mathrm{L}+100 \mathrm{mg} / \mathrm{L}$ vitamin $B_{1}+50 \mathrm{mg} / \mathrm{L}$ vitamin $C$

$11-2 \mathrm{~g}$ yeast $/ \mathrm{L}+100 \mathrm{mg} / \mathrm{L}$ vitamin $B_{1}+100 \mathrm{mg} / \mathrm{L}$ vitamin $C$

$12-4 \mathrm{~g}$ yeast $/ \mathrm{L}+50 \mathrm{mg} / \mathrm{L}$ vitamin $B_{1}+50 \mathrm{mg} / \mathrm{L}$ vitamin $C$

13- $4 \mathrm{~g}$ yeast $/ \mathrm{L}+50 \mathrm{mg} / \mathrm{L}$ vitamin $B_{1}+100 \mathrm{mg} / \mathrm{L}$ vitamin $C$

$14-4 \mathrm{~g}$ yeast $/ \mathrm{L}+100 \mathrm{mg} / \mathrm{L}$ vitamin $B_{1}+50 \mathrm{mg} / \mathrm{L}$ vitamin $C$

$15-4 \mathrm{~g}$ yeast $/ \mathrm{L}+100 \mathrm{mg} / \mathrm{L}$ vitamin $B_{1}+100 \mathrm{mg} / \mathrm{L}$ vitamin $C$ 
These results are in good line with those obtained from the data of vegetative growth in Table 1 in this study, and total yield is the sum of vegetable growth, dry matter accumulation and metabolic activity.

Among the single treatments, data presented in Table 2 show that spraying plants with vitamin $C$ at 50 or $100 \mathrm{mg} / \mathrm{L}$ scores the highest values of number of pods/plant, pod length, pod weight, early yield and total yield than vitamin $B_{1}$, yeast and control. vitamin C functions as antioxidant, an enzyme factor and as growth regulating factor. It participates in a variety of processes, including photosynthesis, photoprotection, cell wall growth and cell expansion, resistance to environmental stresses and synthesis of ethylene, gibberellins, anthocynins and hydroxyproline, which reflect on yield and its components (Midan and El-Dinary,2008).

Meanwhile spraying plants with vitamin $B_{1}$ at 50 or $100 \mathrm{mg} / \mathrm{L}$ had a significant increase on yield and its components than yeast or control (sprayed with water). The effect of vitamin $B_{1}$ may be due to the role of $B_{1}$ which is combined with 2 molecules of phosphoric acid to form thiamine phosphate (TPP) which is the most active form that acts as a coenzyme necessary for oxidative decarboxylation of pyruvic acid from glycolysis to active acetate in Krebs cycle and this in turn affect the growth and yield of plant.

The effect of thiamine may be due to the role of thiamine which is combined with 2 molecules of phosphoric acid to form thiamine pyrophosphate (TPP) which is the most active form that acts as coenzyme necessary for oxidative decarboxylation of pyruvic acid from glycolysis to active acetate in Kreb 's cycle and this in turn affect the growth and yield of plant.

But spraying plants with yeast at 2 or $4 \mathrm{~g} / \mathrm{L}$ had a significant increase on yield and its components than control (sprayed with water). Furthermore, yeast via its cytokinins content (Nagodawithanna 1991) and the high content of vitamin $B_{s}$ and minerals might be play a role in orientation and translocation of metabolites from leaves into the reproductive organs, also, it might play a role in the synthesis of protein and nucleic acid and minimized their degradation (Natio et al.,1981). All of these occurrences and attributes might lead to the improvement of pea yield.

Spraying plants with mixture vitamins $\left(B_{1}\right.$ and $C$ ) and yeast at all concentrations increasing number of pods/plant, pod length, pod weight, early yield and total yield of sugar pea than sprayed by vitamins $\left(B_{1}\right.$ or $C$ ) or yeast alone as well as control. This may be due to the beneficial of vitamins $\left(B_{1}\right.$ and $\left.C\right)$ and yeast together, which reflects on yield and its components. 
Table 2. Effect of vitamins ( $B_{1}$ and $C$ ) and yeast on yield and its components of sugar pea throughout seasons 2007/2008 and 2008/2009.

\begin{tabular}{|c|c|c|c|c|c|c|c|c|c|c|}
\hline \multirow{2}{*}{$\begin{array}{l}\text { Characters } \\
\text { Treatments }\end{array}$} & \multicolumn{2}{|c|}{$\begin{array}{l}\text { Number of } \\
\text { pods/plant }\end{array}$} & \multicolumn{2}{|c|}{$\begin{array}{l}\text { Pod length } \\
(\mathrm{cm})\end{array}$} & \multicolumn{2}{|c|}{$\begin{array}{l}\text { Pod weight } \\
\text { (g) }\end{array}$} & \multicolumn{2}{|c|}{$\begin{array}{l}\text { Early yield } \\
(\mathrm{Mg} / \mathrm{fed})^{*}\end{array}$} & \multicolumn{2}{|c|}{$\begin{array}{l}\text { Total yield } \\
(\mathrm{Mg} / \mathrm{fed})^{*}\end{array}$} \\
\hline & $\begin{array}{c}\text { First } \\
\text { season }\end{array}$ & $\begin{array}{l}\text { Second } \\
\text { season }\end{array}$ & $\begin{array}{c}\text { First } \\
\text { season }\end{array}$ & $\begin{array}{l}\text { Second } \\
\text { season }\end{array}$ & $\begin{array}{c}\text { First } \\
\text { season }\end{array}$ & $\begin{array}{l}\text { Second } \\
\text { season }\end{array}$ & $\begin{array}{c}\text { First } \\
\text { season }\end{array}$ & $\begin{array}{l}\text { Second } \\
\text { season }\end{array}$ & $\begin{array}{c}\text { First } \\
\text { season }\end{array}$ & $\begin{array}{l}\text { Second } \\
\text { season }\end{array}$ \\
\hline 1 & 15.54 & 13.20 & 8.86 & 8.41 & 3.13 & 3.16 & 0.913 & 0.914 & 2.652 & 2.636 \\
\hline Bensultap** & - & - & - & - & - & - & - & - & 3.402 & 3.358 \\
\hline 2 & 15.97 & 13.54 & 9.06 & 9.13 & 3.16 & 3.19 & 0.935 & 0.956 & 2.908 & 2.892 \\
\hline 3 & 17.42 & 14.68 & 9.28 & 8.87 & 3.28 & 3.20 & 0.953 & 0.963 & 2.944 & 2.956 \\
\hline 4 & 18.21 & 15.06 & 9.93 & 9.59 & 3.38 & 3.28 & 0.964 & 0.970 & 3.005 & 3.013 \\
\hline 5 & 16.96 & 15.64 & 9.87 & 9.40 & 3.58 & 3.41 & 0.983 & 0.968 & 2.985 & 3.003 \\
\hline 6 & 19.64 & 16.45 & 10.05 & 9.01 & 3.77 & 3.45 & 1.033 & 1.042 & 3.072 & 3.067 \\
\hline 7 & 19.74 & 16.75 & 10.49 & 9.96 & 3.61 & 3.66 & 1.044 & 1.005 & 3.089 & 3.029 \\
\hline 8 & 18.78 & 16.06 & 10.26 & 10.95 & 3.90 & 3.80 & 1.002 & 1.085 & 3.122 & 3.073 \\
\hline 9 & 19.34 & 17.23 & 10.04 & 10.92 & 3.91 & 3.85 & 1.010 & 1.032 & 3.033 & 3.105 \\
\hline 10 & 19.19 & 16.54 & 10.24 & 10.46 & 4.04 & 3.82 & 1.100 & 1.109 & 3.035 & 3.008 \\
\hline 11 & 19.15 & 17.32 & 10.00 & 10.74 & 4.03 & 3.84 & 1.036 & 1.117 & 3.115 & 3.064 \\
\hline 12 & 19.88 & 15.74 & 10.95 & 10.64 & 4.02 & 3.96 & 1.085 & 1.068 & 3.062 & 3.136 \\
\hline 13 & 18.18 & 17.22 & 10.64 & 10.66 & 4.08 & 4.01 & 1.023 & 1.029 & 3.097 & 3.056 \\
\hline 14 & 18.63 & 17.55 & 10.89 & 10.75 & 4.00 & 4.00 & 1.100 & 1.029 & 3.013 & 3.111 \\
\hline 15 & 19.29 & 16.69 & 10.45 & 10.23 & 3.78 & 4.12 & 1.036 & 1.043 & 3.022 & 3.094 \\
\hline $\mathrm{LSD}_{0.05}$ & 2.00 & 1.82 & 0.47 & 0.78 & 0.26 & 0.22 & 0.075 & 0.053 & 0.092 & 0.092 \\
\hline
\end{tabular}

* Mg (mega gram = million gram) ${ }^{* *}$ Bensultap (pesticide)
1- Control
2- $2 \mathrm{~g}$ yeast/L
3- $4 \mathrm{~g}$ yeast/L

4- $50 \mathrm{mg} / \mathrm{L}$ vitamin $\mathrm{B}_{1}$

5- $100 \mathrm{mg} / \mathrm{L}$ vitamin $B_{1}$

6- $50 \mathrm{mg} / \mathrm{L}$

vitamin C

7- $100 \mathrm{mg} / \mathrm{L}$ vitamin $\mathrm{C}$

8- 2 g yeast/L+

$50 \mathrm{mg} / \mathrm{L}$ vitamin $B_{1}+50 \mathrm{mg} / \mathrm{L}$ vitamin $C$

9- $2 \mathrm{~g}$ yeast $/ \mathrm{L}+50 \mathrm{mg} / \mathrm{L}$ vitamin $B_{1}+100 \mathrm{mg} / \mathrm{L}$ vitamin $C$

10- $2 \mathrm{~g}$ yeast $/ \mathrm{L}+100 \mathrm{mg} / \mathrm{L}$ vitamin $B_{1}+50 \mathrm{mg} / \mathrm{L}$ vitamin $C$

$11-2 \mathrm{~g}$ yeast $/ \mathrm{L}+100 \mathrm{mg} / \mathrm{L}$ vitamin $B_{1}+100 \mathrm{mg} / \mathrm{L}$ vitamin $C$

$12-4 \mathrm{~g}$ yeast $/ \mathrm{L}+50 \mathrm{mg} / \mathrm{L}$ vitamin $B_{1}+50 \mathrm{mg} / \mathrm{L}$ vitamin $C$

13- $4 \mathrm{~g}$ yeast $/ \mathrm{L}+50 \mathrm{mg} / \mathrm{L}$ vitamin $B_{1}+100 \mathrm{mg} / \mathrm{L}$ vitamin $C$

$14-4 \mathrm{~g}$ yeast $/ \mathrm{L}+100 \mathrm{mg} / \mathrm{L}$ vitamin $B_{1}+50 \mathrm{mg} / \mathrm{L}$ vitamin $C$

$15-4 \mathrm{~g}$ yeast $/ \mathrm{L}+100 \mathrm{mg} / \mathrm{L}$ vitamin $B_{1}+100 \mathrm{mg} / \mathrm{L}$ vitamin $C$ 


\section{NPK Contents}

The effect of foliar application with different treatments on mineral contents (NPK) in plants of sugar pea are shown in Table 3. It is obvious from the data that foliar application of vitamins ( $B_{1}$ or $C$ ) or yeast at all concentrations reflect significant effect on all mineral contents (NPK) in plants as compared to control (water spray). Among the single treatments, data indicated that spraying plants with 50 or 100 $\mathrm{mg} / \mathrm{L}$ vitamin C caused a high increase in mineral contents (NPK) more than the effect of spraying with vitamin $B_{1}$ or yeast at all concentrations, and spraying plants with 50 or $100 \mathrm{mg} / \mathrm{L}$ vitamin $B_{1}$ caused a high increase in mineral contents (NPK) more than the effect of spraying with yeast at all concentrations.

A stimulative effect for vitamins ( $B_{1}$ and $\left.C\right)$ and yeast application on mineral contents (NPK) was also reported by Abdel-Aziz (1997), El-Ghamriny et al., (1999) and Midan and El-Dinary (2008).

The best treatment for increasing mineral contents (NPK) in plants of sugar pea plants was spraying plants with mixture vitamins ( $B_{1}$ and $C$ ) and yeast at all concentrations under study as compared to sprayed by vitamins $\left(B_{1}\right.$ or $\left.C\right)$ or yeast alone as well as control. This may be due to spray with mixture vitamins $\left(B_{1}\right.$ and $\left.C\right)$ and yeast gave the beneficial of them together, which reflects on mineral contents (NPK) in plants of sugar pea.

\section{NPK Uptake}

Data in Table 4 show the effect of spraying with different treatments on mineral uptake. It is obvious from the data that foliar application of vitamins $B_{1}, C$ or yeast at all concentrations reflect significant effect on all mineral uptake (NPK) in plants as compared to control (water spray).

Vitamin $C$ reflected increase on mineral uptake more than vitamin $B_{1}$ or yeast at all concentrations, and vitamin $B_{1}$ superior than those of yeast at all concentrations. In general, the best treatment for increasing mineral uptake (NPK) in plants of sugar pea was spraying plants with mixture vitamins $B_{1}$ and $C$ and yeast at all concentrations under study as compared to sprayed by vitamins $B_{1}, C$ or yeast alone as well as control.

\section{Total protein, Total Carbohydrates and Total Soluble Solids}

Concerning the effect of spraying plants with vitamins $B_{1}, C$ and yeast and different combination treatments among them as well as water spray (control) on total protein, total carbohydrates and total soluble solids in pods, results in Table 5 show that all spraying materials promoted total protein, total carbohydrates and total soluble solids in pods as compared to control (sprayed water). 
Table 3. Effect of vitamins (B1 and C) and yeast on NPK contents in sugar pea plants throughout seasons 2007/2008 and 2008/2009.

\begin{tabular}{|c|c|c|c|c|c|c|}
\hline \multirow[b]{2}{*}{ Treatments } & \multicolumn{2}{|c|}{$\begin{array}{l}\mathrm{N} \\
\%\end{array}$} & \multicolumn{2}{|c|}{$\begin{array}{l}\mathrm{P} \\
\%\end{array}$} & \multicolumn{2}{|c|}{$\begin{array}{l}K \\
\%\end{array}$} \\
\hline & $\begin{array}{c}\text { First } \\
\text { season }\end{array}$ & $\begin{array}{l}\text { Second } \\
\text { season }\end{array}$ & $\begin{array}{c}\text { First } \\
\text { season }\end{array}$ & $\begin{array}{l}\text { Second } \\
\text { season }\end{array}$ & $\begin{array}{c}\text { First } \\
\text { season }\end{array}$ & $\begin{array}{l}\text { Second } \\
\text { season }\end{array}$ \\
\hline 1 & 3.06 & 2.99 & 0.34 & 0.31 & 2.10 & 2.04 \\
\hline 2 & 3.10 & 3.08 & 0.35 & 0.32 & 2.12 & 2.11 \\
\hline 3 & 3.13 & 3.10 & 0.35 & 0.33 & 2.14 & 2.13 \\
\hline 4 & 3.16 & 3.12 & 0.36 & 0.35 & 2.16 & 2.17 \\
\hline 5 & 3.17 & 3.13 & 0.37 & 0.36 & 2.21 & 2.20 \\
\hline 6 & 3.20 & 3.15 & 0.39 & 0.37 & 2.28 & 2.23 \\
\hline 7 & 3.20 & 3.17 & 0.37 & 0.38 & 2.25 & 2.23 \\
\hline 8 & 3.22 & 3.21 & 0.38 & 0.39 & 2.33 & 2.28 \\
\hline 9 & 3.23 & 3.23 & 0.39 & 0.39 & 2.30 & 2.29 \\
\hline 10 & 3.26 & 3.23 & 0.40 & 0.40 & 2.35 & 2.31 \\
\hline 11 & 3.25 & 3.24 & 0.40 & 0.41 & 2.37 & 2.34 \\
\hline 12 & 3.29 & 3.26 & 0.40 & 0.41 & 2.36 & 2.35 \\
\hline 13 & 3.31 & 3.27 & 0.41 & 0.42 & 2.37 & 2.35 \\
\hline 14 & 3.31 & 3.28 & 0.41 & 0.42 & 2.37 & 2.35 \\
\hline 15 & 3.22 & 2.95 & 0.42 & 0.43 & 2.37 & 2.37 \\
\hline $\mathrm{LSD}_{0.05}$ & 0.11 & 0.15 & 0.04 & 0.08 & 0.05 & 0.05 \\
\hline
\end{tabular}

1- Control 2- $2 \mathrm{~g}$ yeast/L 3- $4 \mathrm{~g}$ yeast/L

4- $50 \mathrm{mg} / \mathrm{L}$ vitamin $\mathrm{B}_{1}$ 5- $100 \mathrm{mg} / \mathrm{L}$ vitamin $B_{1}$ 6- $50 \mathrm{mg} / \mathrm{L}$ vitamin C 7- $100 \mathrm{mg} / \mathrm{L}$ vitamin C 8- 2 g yeast/L+ $50 \mathrm{mg} / \mathrm{L}$ vitamin $B_{1}+50 \mathrm{mg} / \mathrm{L}$ vitamin $C$

9- $2 \mathrm{~g}$ yeast $/ \mathrm{L}+50 \mathrm{mg} / \mathrm{L}$ vitamin $B_{1}+100 \mathrm{mg} / \mathrm{L}$ vitamin $C$ 10- $2 \mathrm{~g}$ yeast $/ \mathrm{L}+100 \mathrm{mg} / \mathrm{L}$ vitamin $B_{1}+50 \mathrm{mg} / \mathrm{L}$ vitamin $C$ $11-2 \mathrm{~g}$ yeast $/ \mathrm{L}+100 \mathrm{mg} / \mathrm{L}$ vitamin $B_{1}+100 \mathrm{mg} / \mathrm{L}$ vitamin $C$ $12-4 \mathrm{~g}$ yeast $/ \mathrm{L}+50 \mathrm{mg} / \mathrm{L}$ vitamin $B_{1}+50 \mathrm{mg} / \mathrm{L}$ vitamin $C$ $13-4 \mathrm{~g}$ yeast $/ \mathrm{L}+50 \mathrm{mg} / \mathrm{L}$ vitamin $B_{1}+100 \mathrm{mg} / \mathrm{L}$ vitamin $C$ 14- $4 \mathrm{~g}$ yeast $/ \mathrm{L}+100 \mathrm{mg} / \mathrm{L}$ vitamin $B_{1}+50 \mathrm{mg} / \mathrm{L}$ vitamin $C$ $15-4 \mathrm{~g}$ yeast $/ \mathrm{L}+100 \mathrm{mg} / \mathrm{L}$ vitamin $B_{1}+100 \mathrm{mg} / \mathrm{L}$ vitamin $C$ 
Table 4. Effect of vitamins (B1 and C) and yeast on NPK uptake (mg/plant) of sugar pea plants throughout seasons 2007/2008 and 2008/2009.

\begin{tabular}{|c|c|c|c|c|c|c|}
\hline \multirow{2}{*}{$\begin{array}{l}\text { Characters } \\
\text { Treatments }\end{array}$} & \multicolumn{2}{|c|}{$\begin{array}{c}\mathrm{N} \\
\text { uptake }\end{array}$} & \multicolumn{2}{|c|}{$\begin{array}{c}\mathrm{P} \\
\text { uptake }\end{array}$} & \multicolumn{2}{|c|}{$\begin{array}{c}\mathrm{K} \\
\text { uptake }\end{array}$} \\
\hline & $\begin{array}{c}\text { First } \\
\text { season }\end{array}$ & $\begin{array}{l}\text { Second } \\
\text { season }\end{array}$ & $\begin{array}{c}\text { First } \\
\text { season }\end{array}$ & $\begin{array}{l}\text { Second } \\
\text { season }\end{array}$ & $\begin{array}{c}\text { First } \\
\text { season }\end{array}$ & $\begin{array}{l}\text { Second } \\
\text { season }\end{array}$ \\
\hline 1 & 23.16 & 227.5 & 2.57 & 23.6 & 15.90 & 155.2 \\
\hline 2 & 24.46 & 237.5 & 2.76 & 24.7 & 16.57 & 162.7 \\
\hline 3 & 24.41 & 231.0 & 2.73 & 24.6 & 16.69 & 158.7 \\
\hline 4 & 25.25 & 250.8 & 2.88 & 28.1 & 17.26 & 174.5 \\
\hline 5 & 25.46 & 250.7 & 2.97 & 28.8 & 17.75 & 176.2 \\
\hline 6 & 25.57 & 268.1 & 3.12 & 31.5 & 18.22 & 189.8 \\
\hline 7 & 28.19 & 268.2 & 3.26 & 32.1 & 19.82 & 188.7 \\
\hline 8 & 28.40 & 292.8 & 3.35 & 35.6 & 20.55 & 207.9 \\
\hline 9 & 301.0 & 302.0 & 36.3 & 36.5 & 214.4 & 214.1 \\
\hline 10 & 292.7 & 288.1 & 35.9 & 35.7 & 211.0 & 206.1 \\
\hline 11 & 313.3 & 284.5 & 38.6 & 36.0 & 228.5 & 205.4 \\
\hline 12 & 3139 & 301.6 & 38.2 & 37.9 & 225.1 & 217.4 \\
\hline 13 & 315.4 & 311.6 & 39.1 & 40.0 & 225.9 & 223.9 \\
\hline 14 & 306.2 & 308.3 & 37.9 & 39.5 & 219.2 & 220.9 \\
\hline 15 & 309.4 & 280.0 & 40.4 & 40.8 & 227.8 & 224.9 \\
\hline $\mathrm{LSD}_{0.05}$ & 14.65 & 11.65 & 6.45 & 7.96 & 12.56 & 5.78 \\
\hline
\end{tabular}

1- Control 2- $2 \mathrm{~g}$ yeast/L

3- $4 \mathrm{~g}$ yeast/L

4- $50 \mathrm{mg} / \mathrm{L}$ vitamin $\mathrm{B}_{1}$

5- $100 \mathrm{mg} / \mathrm{L}$ vitamin $B_{1}$ 6- $50 \mathrm{mg} / \mathrm{L}$ vitamin $\mathrm{C}$ 7- $100 \mathrm{mg} / \mathrm{L}$ vitamin $\mathrm{C}$

8- 2 g yeast/L+

$50 \mathrm{mg} / \mathrm{L}$ vitamin $B_{1}+50 \mathrm{mg} / \mathrm{L}$ vitamin $C$

9- $2 \mathrm{~g}$ yeast $/ \mathrm{L}+50 \mathrm{mg} / \mathrm{L}$ vitamin $B_{1}+100 \mathrm{mg} / \mathrm{L}$ vitamin $C$ 10- $2 \mathrm{~g}$ yeast $/ \mathrm{L}+100 \mathrm{mg} / \mathrm{L}$ vitamin $B_{1}+50 \mathrm{mg} / \mathrm{L}$ vitamin $C$ 11- $2 \mathrm{~g}$ yeast $/ \mathrm{L}+100 \mathrm{mg} / \mathrm{L}$ vitamin $B_{1}+100 \mathrm{mg} / \mathrm{L}$ vitamin $C$ $12-4 \mathrm{~g}$ yeast $/ \mathrm{L}+50 \mathrm{mg} / \mathrm{L}$ vitamin $B_{1}+50 \mathrm{mg} / \mathrm{L}$ vitamin $C$ 13- $4 \mathrm{~g}$ yeast/L+ $50 \mathrm{mg} / \mathrm{L}$ vitamin $B_{1}+100 \mathrm{mg} / \mathrm{L}$ vitamin $C$ $14-4 \mathrm{~g}$ yeast $/ \mathrm{L}+100 \mathrm{mg} / \mathrm{L}$ vitamin $B_{1}+50 \mathrm{mg} / \mathrm{L}$ vitamin $C$ $15-4 \mathrm{~g}$ yeast $/ \mathrm{L}+100 \mathrm{mg} / \mathrm{L}$ vitamin $B_{1}+100 \mathrm{mg} / \mathrm{L}$ vitamin $C$ 
Table 5. Effect of vitamins (B1 and C) and yeast on total protein, total carbohydrates and total soluble solid in pods of sugar pea throughout seasons $2007 / 2008$ and 2008/2009.

\begin{tabular}{|c|c|c|c|c|c|c|}
\hline \multirow[b]{2}{*}{ Treatments } & \multicolumn{2}{|c|}{$\begin{array}{c}\text { Total } \\
\text { protein }(\%)\end{array}$} & \multicolumn{2}{|c|}{ Total carbohydrates (\%) } & \multicolumn{2}{|c|}{ TSS } \\
\hline & $\begin{array}{c}\text { First } \\
\text { season }\end{array}$ & $\begin{array}{l}\text { Second } \\
\text { season }\end{array}$ & $\begin{array}{c}\text { First } \\
\text { season }\end{array}$ & $\begin{array}{l}\text { Second } \\
\text { season }\end{array}$ & $\begin{array}{c}\text { First } \\
\text { season }\end{array}$ & $\begin{array}{l}\text { Second } \\
\text { season }\end{array}$ \\
\hline 1 & 19.13 & 18.69 & 33.93 & 32.76 & 10.11 & 9.74 \\
\hline 2 & 19.38 & 19.25 & 34.50 & 33.32 & 10.15 & 10.15 \\
\hline 3 & 19.56 & 19.38 & 34.64 & 34.80 & 10.35 & 10.24 \\
\hline 4 & 19.75 & 19.50 & 35.89 & 34.66 & 10.34 & 10.40 \\
\hline 5 & 19.81 & 19.56 & 36.80 & 35.75 & 10.47 & 10.57 \\
\hline 6 & 20.00 & 19.69 & 36.52 & 36.19 & 10.51 & 10.57 \\
\hline 7 & 20.00 & 19.81 & 37.74 & 36.19 & 10.68 & 10.66 \\
\hline 8 & 20.13 & 20.06 & 37.82 & 37.72 & 10.80 & 10.76 \\
\hline 9 & 20.19 & 20.19 & 38.96 & 37.25 & 10.96 & 10.85 \\
\hline 10 & 20.38 & 20.19 & 39.86 & 38.61 & 11.19 & 10.85 \\
\hline 11 & 20.31 & 20.25 & 40.01 & 37.75 & 11.29 & 11.07 \\
\hline 12 & 20.56 & 20.38 & 39.52 & 39.30 & 11.50 & 11.45 \\
\hline 13 & 20.69 & 20.44 & 40.56 & 38.76 & 11.71 & 11.17 \\
\hline 14 & 20.69 & 20.50 & 39.23 & 37.75 & 11.77 & 11.47 \\
\hline 15 & 20.13 & 18.44 & 39.28 & 38.20 & 11.64 & 11.32 \\
\hline $\mathrm{LSD}_{0.05}$ & 0.02 & 0.19 & 1.72 & 1.00 & 0.28 & 0.23 \\
\hline
\end{tabular}

1- Control

4- $50 \mathrm{mg} / \mathrm{L}$ vitamin $\mathrm{B}_{1}$ vitamin C
2- $2 \mathrm{~g}$ yeast/L

5- $100 \mathrm{mg} / \mathrm{L}$ vitamin $\mathrm{B}_{1}$

3- $4 \mathrm{~g}$ yeast/L
6- $50 \mathrm{mg} / \mathrm{L}$

8- 2 g yeast/L+

$50 \mathrm{mg} / \mathrm{L}$ vitamin $B_{1}+50 \mathrm{mg} / \mathrm{L}$ vitamin $C$

9- $2 \mathrm{~g}$ yeast $/ \mathrm{L}+50 \mathrm{mg} / \mathrm{L}$ vitamin $B_{1}+100 \mathrm{mg} / \mathrm{L}$ vitamin $C$

10- $2 \mathrm{~g}$ yeast $/ \mathrm{L}+100 \mathrm{mg} / \mathrm{L}$ vitamin $B_{1}+50 \mathrm{mg} / \mathrm{L}$ vitamin $C$

11- $2 \mathrm{~g}$ yeast $/ \mathrm{L}+100 \mathrm{mg} / \mathrm{L}$ vitamin $B_{1}+100 \mathrm{mg} / \mathrm{L}$ vitamin $C$

$12-4 \mathrm{~g}$ yeast $/ \mathrm{L}+50 \mathrm{mg} / \mathrm{L}$ vitamin $B_{1}+50 \mathrm{mg} / \mathrm{L}$ vitamin $C$

13- $4 \mathrm{~g}$ yeast $/ \mathrm{L}+50 \mathrm{mg} / \mathrm{L}$ vitamin $B_{1}+100 \mathrm{mg} / \mathrm{L}$ vitamin $C$

14- $4 \mathrm{~g}$ yeast $/ \mathrm{L}+100 \mathrm{mg} / \mathrm{L}$ vitamin $B_{1}+50 \mathrm{mg} / \mathrm{L}$ vitamin $C$

$15-4 \mathrm{~g}$ yeast $/ \mathrm{L}+100 \mathrm{mg} / \mathrm{L}$ vitamin $B_{1}+100 \mathrm{mg} / \mathrm{L}$ vitamin $C$ 
Vitamin $C$ caused a significant increase than vitamin $B_{1}$ and yeast, while sprayed plants with yeast gave the lowest values as compared to vitamins ( $B_{1}$ and $C)$. Spraying plants with mixture vitamins $\left(B_{1}\right.$ and $C$ ) and yeast at all concentrations increasing total protein, total carbohydrates and total soluble solids in pods

\section{Entomological Studies}

Under field conditions, all materials sprayed were affected directly on pest via the mineral nutritional status of the plants, and indirectly by producing healthy plants. The most abundant insects on legume crops are leaf miner (Liriomyza pisi.), aphid (Aphis craccivora) and mite (Tetranychus urtica), which causes high yield losses. Studies were taken to examine the population build up of this pests and its correlation with the magnitude of NPK contents in leaf extracts of sugar pea.

\section{1- Efficacy of Liriomyza pisi}

Table 6 show the numbers and percentage reductions of Liriomyza pisi. infesting sugar pea. It can be seen the Liriomyza pisi. started to appear in the $2^{\text {nd }}$ week of Nov. in two seasons, the population density increased gradually in control treatment and reached in maximum during the $1^{\text {st }}$ week of Jan. in first season and $3^{\text {rd }}$ week of Jan. in second season. Lel Dash and Abo Shaeshae (2001) who found that the highest average number of serpentine leaf miner larvae (Liriomyza trifoli) on pea plants was observed during Dec. and Jan.

Concerning the mean of \% reduction, data indicated that, treated plants by $4 \mathrm{~g}$ yeast $+100 \mathrm{mg} / \mathrm{L}$ vitamin $B_{1}+100 \mathrm{mg} / \mathrm{L}$ vitamin $C$ recorded high $\%$ reduction $(29.96 \%)$ in first season, while treated plants by $100 \mathrm{mg} / \mathrm{L}$ vitamin $B_{1}$ recorded the lowest levels of \% reduction (-34.77).

On the other hands at second season, treated plants by $2 \mathrm{~g}$ yeast $+100 \mathrm{mg} / \mathrm{L}$ vitamin $B_{1}+100 \mathrm{mg} / \mathrm{L}$ vitamin $C$ recorded high \% reduction (40.04), while treated plants by $2 \mathrm{~g}$ yeast recorded the lowest level of \% reduction

(- 15.83). This results indicated that the important role of vitamin $B_{1}$ and vitamin $C$ in the plant physiological healthy which capable to resist the insect.

Theses results agree with those obtained by Nicholas and Wheeler (2000) who noticed that plants sprayed with vitamin $B_{1}$ or $C$ enhanced the status of plant physiology including photosynthesis, photoprotection and cell wall growth.

\section{2- Efficacy on Aphis craccivora}

Table 7 shows the numbers and percentage reductions of Aphis craccivora infesting sugar pea. From this Table, it can be seen that the population density increased gradually in control treatment until the end of season, and increased gradually in yeast treatment until the $3^{\text {rd }}$ week of Jan., while the plants treated with vitamins $\left(B_{1}\right.$ or $\left.C\right)$ at two concentrations increased gradually until the $3^{\text {ed }}$ week after 
the $3^{\text {rd }}$ spray. These phenomena indicated that yeast was more suitable to insect feeding. This may be due to the highest plant uptake of nitrogen, which necessary factor of making plant sap. These results agree with those obtained by Omaima (2009) who found that spraying snap bean plants by yeast at $1 \mathrm{~kg} / 100 \mathrm{~L}$ water increased nitrogen uptake, also Abdel-Aziz (1997) found that spray tomato plants by baker yeast at $1 \mathrm{~kg} / 200 \mathrm{~L}$ water increased nitrogen uptake.

Also, the chemical composition of sugar pea plants and it's correlation with aphids occurrence were studied. The chemical composition of plants may be playing good role at two axis, nutrition of plant and feeding of aphid in this respect, the higher nitrogen extract plus appropriate protein and lower dry matter in plant sap lead to increases the population of aphid. Data show that plants treated by $100 \mathrm{mg} / \mathrm{L}$ vitamin $B_{1}+100 \mathrm{mg} / \mathrm{L}$ vitamin $\mathrm{C}+4 \mathrm{~g}$ yeast/L infested with mean numbers 2.94 individ./10 leaflets and 2.04 individ./10 leaflets in first and second seasons respectively. These results agree with those obtained by Darwish (1991) who sited that the occurrence of aphid contributed with high moisture of plant and decrease of dry matter (\%), which seem to be obligator to the existence of aphid.

Generally, the plants treated by vitamins ( $B_{1}$ and $C$ ) and yeast recorded the highest population and the highest yield in two seasons. In first season, plants treated with $50 \mathrm{mg} / \mathrm{L}$ vitamin $B_{1}+100 \mathrm{mg} / \mathrm{L}$ vitamin $\mathrm{C}+4 \mathrm{~g}$ yeast caused $51.4 \% \mathrm{R}$ in population of aphid and gave $3.357 \mathrm{Mg} /$ fed. While this treatment in second season caused $30.73 \% \mathrm{R}$ in population of aphid and gave $3.356 \mathrm{Mg} / \mathrm{fed}$. The mean number of aphid attacked untreated check was 5.34 and 5.29 individ./10 leaflets in first and second seasons respectively. These finding are in partial agreement with those of ElSerafi et al., (2000).

Concerning the plants treated with recommended pesticide (bensultap $50 \%$ $\mathrm{Wp}$ ), it was recorded $94.52 \% \mathrm{R}$ in population of aphid and gave $3.402 \mathrm{Mg} / \mathrm{fed}$ in first season, while recorded $91.37 \% \mathrm{R}$ in population of aphid and gave $3.358 \mathrm{Mg} / \mathrm{fed}$ in second season. This results indicated that the spray with vitamin $B_{1}+$ vitamin $C+$ yeast was more suitable to aphids feeding and in the same time was sufficient to giving plants sap which sufficient to both insect and plant. Those results may be due to reduce misuse of insecticides.

\section{3- Efficacy on Tetranychus urtica}

The correlation between a recommended pesticide against moving stages of infesting sugar pea and spraying by fifteen formulas from three materials (vitamin $B_{1}$, vitamin $\mathrm{C}$, yeast and different combination treatments among them as well as control) during two successive seasons were shown in Table 8. All plots injured with mite during the two seasons but with different levels of infestation. The population of 
mite (moving stages) was the lowest in the first three weeks then followed by increase until the end of both seasons. Regarding the mean number of mite, there was a significant difference among the three tested materials.

During first season, all plants harboured the lowest number of mite, the mean number ranged between 0.1 to 0.7 indivil./10 leaflets, while increased gradually in control treatment until the end of both seasons. Moving stages of mite began with lowest number during the three inspections, while increased during the following eight inspections, and then decreased in mean numbers till the end of season during the two successive seasons. The mean number of mite population at check plots in first season was 4.84 indivil./10 leaflets, while it was 7.18 indivil./10 leaflets in second season. The previous results are generally in agreement with Darwish et al., (1996).

The highest mean number of mite population in treatments in first seasons was 8.09 indivil./10 leaflets caused $-5.65 \% \mathrm{R}$ in population of mite which occurred in (2 g yeast $+50 \mathrm{mg}$ vitamin $B_{1} / L+50 \mathrm{mg}$ vitamin $C / L$ ), while in second season was 7.69 indivil./10 leaflets caused $9.1 \% \mathrm{R}$ in population of mite.

On the other hand, the lowest mean number of mite population from all treatments in first season was 1.86 indivil./10 leaflets caused $7.12 \% \mathrm{R}$ in population which occurred in ( $4 \mathrm{~g}$ yeast/L), while in second season was 1.1 indivil./10 leaflets caused $10.97 \% \mathrm{R}$ in $50 \mathrm{mg}$ vitamin C/L.

Concerning the results of two seasons and it's contributed with data resulted ins and outs NPK and yield. Its clear that plants treated with vitamin $B_{1}$, vitamin $C$ or yeast were caused high infestation with mite and high yield, while plants treated with $\left(4 \mathrm{~g}\right.$ yeast $+50 \mathrm{mg}$ vitamin $B_{1} / \mathrm{L}+50 \mathrm{mg}$ vitamin $C / L$ ) caused low infestation with mite and acceptable yield.

On the other hand, the plots treated with $\left(4 \mathrm{~g}\right.$ yeast $+100 \mathrm{mg}$ vitamin $\mathrm{B}_{1} / \mathrm{L}+$ $100 \mathrm{mg}$ vitamin $\mathrm{C} / \mathrm{L}$ ) caused moderate infestation with mite and high yield. Also, the plots treated with bensultap $50 \%$ Wp caused high \% R (74.59 and 83.94\% R) in two seasons, respectively, and gave the high yield.

Generally, these results indicated that treatment with $4 \mathrm{~g}$ yeast $+100 \mathrm{mg}$ vitamin $B_{1} / L+100 \mathrm{mg}$ vitamin $C / L$ was sufficient nutrient for both plants and in the same time to feeding three tested pests. These results showed that the natural materials can a play an effective role in checking the piercing sucking pests in sugar pea crop. This result showed the great current concern about the environment indicates a need to limit application of chemical for lank pests control. These results agree with those obtained by Faris et al., (2004). 
INFLUENCE OF CERTAIN BIO AND CHEMICAL TREATMENTS ON SUGAR PEA PRODUCTIVITY AND PROTECTION OF SOME INSECT PESTS 
INFLUENCE OF CERTAIN BIO AND CHEMICAL TREATMENTS ON SUGAR PEA PRODUCTIVITY AND PROTECTION OF SOME INSECT PESTS 
INFLUENCE OF CERTAIN BIO AND CHEMICAL TREATMENTS ON SUGAR PEA PRODUCTIVITY AND PROTECTION OF SOME INSECT PESTS 


\section{REFERENCES}

1. Abdel-Aziz, M. A. 1997. Response of tomato plants to nitrogen fertilizer levels and growth regulators. M.Sc. Thesis, Dept. of Vegetable crops, Fac. of Agric. Cairo Univ. Egypt.

2. Bijjur, S. and S. Verma. 1996. Effect of a biotic factors on the pests of pea and natural enemies. Indian J. Entomol., 3: 233-239.

3. Bremner, J. M. and C. S. Mulvaney. 1982. Total nitrogen: Page, A. L., R. H. Miller, and D. R. Keeney (Eds.). Methods of Soil Analysis. Part 2, Amer. Soc. Agron., Madison, W. I., USA., pp. 595-624.

4. Darwish, E.T.E. 1991. Chemical composition of host plant foliages and their role in the occurrence of two mealy aphid species. Minufiya J. Agric. Res., 16 (2).

5. Darwish, M. A., M.K. Megali, A.M. Gaber and K. F. Iskandar. 1996. Evaluation of certain pea varieties for susceptibility to natural infestation with two spotted spider mite in Egypt. Al-Azhar Agric. Res., 23: 233-238.

6. Dubois, M., R.A. Gilles, J.Hamillon, R.Rebers, and I. Smith. 1956. Colorimetric method for determination of sugars and related substances. Anal. Chem. 28: 350 .

7. El-Ghamriny, E. A., H. M. E. Arisha and K. A. Nour. 1999. Studies on tomato flowering, fruit set, yield and quality in summer season. 1- Spraying with thiamine, ascorbic acid and yeast. Zagazig J. Agric. Res., 26 (5)1345-1364.

8. El-Serafi, H.A.K., A.A. Ghanim and M. El-adl. 2000. Ecological studies on piercingsucking insects infesting sweet pea plantation at Mansoura district. J. Agric. Sci. Mansoura Univ., 25 (11) 7179-7190.

9. Faris, S.F.S., Nadia H. Habashy and Aida K.F. Iskander. 2004. relation ship between infestation with different stages of the spider mite Tetranychus urtica (Koch) on seventeen tomato varieties and plant age with special reference to vegetative and yield physical characters. J. Agric. Sci. Mansoura Univ., 29 (6) 3567-3579.

10. Henderson, C.F. and E.W. Tilton. 1955. tests with acaricids against the brown wheat mite. J. Econ. Entomol. 48: 157-161.

11. Jackson, M. L. 1970. Soil Chemical Analysis. Prentic Hall, Englewood Ceiffs, N. J.

12. Kamel, A.E. 2005. Studies on some factors affecting growth and productivity of cowpea crop. Ph.D. Thesis, Fac. Agric., Zagazig Univ., Egypt.

13. Kodandara N.J. and P.G. Rao. 1985. Influence of p-Bitamins on stomatal index, frequency and diurnal rhythms in stomatal opening in Cyamopsis tetraganoloha (L.) Taub. J. Biol. Res. 5: 68-73. 
14. Lel Dash, A.A. and A.A. Abo Shaeshae. 2001. Abundance and dynamics of larval population of the serpentine leaf miner, Liriomyza trifolii (Burgess) (Diptera: Agromyzidae) on some leguminous plants. J. Adv. Agric. Res., 6 (4) 1007 - 1019.

15. Megali, M.K., S.A.G. Metwally and F. Faris. 1992. Evaluation of some pea cultivars to leaf miner, thrips and two spotted spider mite with reference to yield and yield components. Zagazig J. Agric. Res., 19 (4) 1897-1905.

16. Midan, S. A. and M. E. El-Dinary. 2008. Antioxidants application in relation to garlic growth, bulbs yield and disease incidence. Zagazic J. Agric. Res., 35 (1) 33-46.

17. Nagodawithana, W. T. 1991. Yeast technology. Universal foods corporation Milwaukee, Wisconsin. Published by Van Nostrand Reinhold, New York. P. 273.

18. Natio, K., S. Nagamo, K. Furye and H. Suzuki. 1981. Effect of benzyladenine on RNA and protein synthesis in intact bean leaves at various stages of ageing. Physiol. Plant, 52: 343-348.

19. Nicholas, S. and L. W. Wheeler. 2000. Ascorbic acid in plants: Biosynthesis and function. Current Review in Plant Science, 19 (41) 267-290.

20. Olsen, S. R. and L. E. Sommers. 1982. Phosphorus. In: Page, A. L., R. H. Miller, and D. R. Keeney (Eds.). Methods of Soil Analysis. Part 2, Amer. Soc. Agron., Madison, W. I., USA., pp. 403-430.

21. Omaima, O.M.A. 2009. Effect of foliar spray with some organic and mineral materials on yield quality and storageability of snap bean. Ph.D. Thesis, Fac. of Agric. Zagazig Univ.

22. Snedecor, G.W. and W.G. Cochran. 1980. Statistical Mathods, 7th ed. Iowa State Univ., Press, Ames, Iowa, U.S.A.

23. Yamauchi, N. and E. W. Alley. 1991. Regulated chlorophyll degradation in spinach leaves during storage. J. Amer. Soc. Hort. Sci., 116 (1) 58-62.

24. Zashchita, R. 1991. Basic measures for the protection of vegetable crops. J. Article, Russian, 6: 34-35. 


\title{
تأثير بعض المعاملات الحيوية والكيميائية على إنتاجيه البسلة السكرية والحماية من بعض الآفات
}

\author{
طه بغدادى على 1 عاطف عبدالقتاح أحمد عبدالله \\ ا ـ قسم بحوث الخضر- معهز بحوث البساتين- مركز البحوث النزراعية

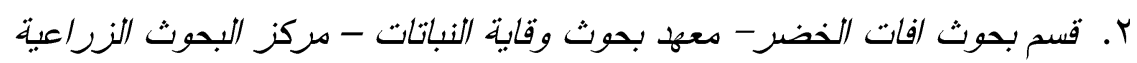

أجريت هذة الدر اسة فى الموسم الشتوى لعامى 2008/2007 ، 2009/2008 بمزرعة

التجارب البحثية بمحطة بحوث البساتين بالقصاصين - محافظة الاسماعيلية، وذلك لدار اسة تأثير الرش بالفيتامينات (فيتامين ب 1 ، فيتامين ج ) بمعدلات 50 ، 100 ملليجر ام/لتز ، و والخميرة بمعدلات 2، 4 جم/لتر ومختلف معاملات التوافيق بينهم على النمو الخضرى و المحصول ومكوناته

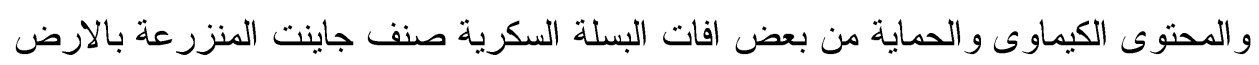
الرملية مع نظام الرى بالتتقيط.

اوضحت النتائج تحسن فى النمو الخضرى و المحصول ومكوناته و المحتوى الكيماوى مع كل

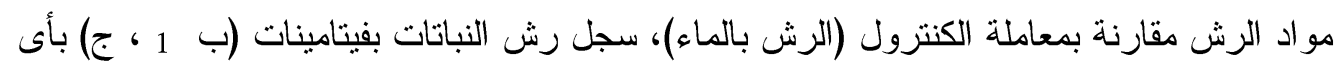

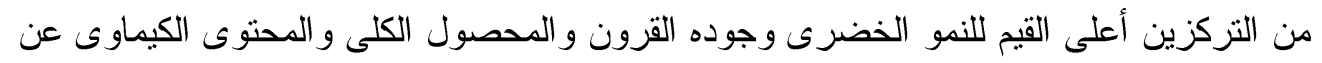
الرش بالخميرة او معاملة الكنترول.

عموما، أظهر رش النباتات بمخلوط من فيتامينات(ب 1 ، ج) و الخميرة عند كل التركيز ات

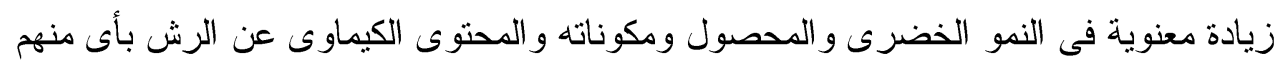
منفردا أو معاملة الكنترول.

قد عضدت الدراسة السابقة من خلال الدراسة الحشرية التى اوضحت ان:

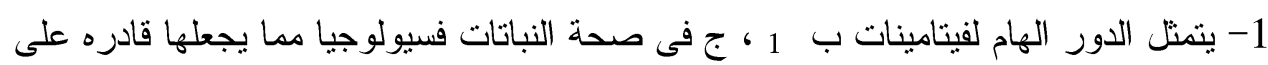
مقاومة الافات محل الدر اسة.

2- النباتات المعاملة بالخميرة تكون اكثر عرضة للاصدابة بالافأت لان الخمبرة اكثز ملائمة لتغذية الافات محل الدر اسة. 2- النباتات المعاملة ب 100 ملليجر ام/لتر من فيتامينات ب1 ، ج ، 4 جرام/لتز خميرة تكون كافية لتغذية النباتات وفى نفس الوقت تغذية الافات محل الدراسة. ولذلك، فأن هذه النتائج توضح الدور الهام لمكافحة الافات مع المحافظة على البيئة بالحد من فن الندات 